\title{
Water quality management in Lake Kinneret (Israel): hydrological and food web perspectives
}

\author{
Moshe GOPHEN \\ Kinneret Limnological Laboratory - Emeritus, MIGAL - Galilee Technological Center, PO Box 831, Kiryat Shmone (11016), Israel \\ e-mail: Gophen@Migal.org.il
}

\begin{abstract}
Long term (1969-2001) data record of nutrient and plankton temporal distribution, and hydrological parameters in Lake Kinneret, combined with metabolic parameters of zooplankton, which were experimentally measured, were statistically (ANOVA) analyzed. Trophic relations between food web compartments were quantitatively considered to evaluate directional combination of ecological forces. Monthly data of inflow discharges, and lake volume were used to calculate residence time values and the data were incorporated into the ecological analysis. The seasonal fluctuations of the hydrological parameters, nutrients, and plankton inventories represent typical subtropical climate conditions: high level in winter and low in summer months. It was found that nitrogen inventories in the lake declined and the biomass of grazable phytoplankton was enhanced since early 1980's. Dissolved phosphorus was decreased mostly in summer months when the lake is nutrient limited, as a result of phytoplankton uptake. Zooplankton was declined until 1993 and increased later. Zooplankton preferably feed on chlorophytes and diatoms with supplemental resources of detritus, bacteria and protozoa. The most abundant zooplanktivorous fish, Lavnun (Bleak, Acanthobrama spp.) populated the lake very densely during 1993-95 and biomanipulation management of subsidized fishery caused lowering of predation pressure resulted in zooplankton enhancement and suppression of additional primary produced matter. It is concluded that zooplankton in Lake Kinneret is not food limited and fishery management (Lavnun removal) might be efficient to enhance zooplankton grazing capacity and algal suppression if phosphorus flux is reduced. Long term changes of nano-phytoplankton are affected by both phosphorus availability and zooplankton grazing and fish predation has a significant impact on zooplankton density. Fishery management aimed at algal suppression might be efficient if phosphorus supply is reduced. The similarity between seasonal fluctuations of food web components and residence time is a result of the natural subtropical conditions. The major effect on nutrient loads is due to inputs from the catchment and to a lesser extend to internal processes. Consequently, management implications aimed at lake water quality protection should be mostly directed towards nutrient removal in the drainage basin and loads reduction by pumping water for supply. When such a management is successfully implemented biomanipulation (fish removal) might be efficient.
\end{abstract}

Key words: Kinneret, residence time, plankton, nutrients, fish

\section{INTRODUCTION}

Lake Kinneret, the only natural freshwater lake in Israel, supplies $\sim 30 \%$ of the national water demands and $\sim 55 \%$ of drinking water requirements. The National Water Carrier convey $200-400 \times 10^{6} \mathrm{~m}^{3}$ annually and about $100 \times 10^{6} \mathrm{~m}^{3}$ removed from the lake by local consumers. The lake is a warm monomictic body of water which is stratified from May to mid December (anoxic hypolimnion) and totally mixed during Mid December through April. During the last 60 years the Kinneret ecosystem has undergone natural and man-made modifications and hydrological extremes: construction of the south dam (1932/3); drying of Hula Lake and swamps (1950's); salty springs diversion (1964); the National Water Carrier operation (1964); implementation of the Hula Project (1994-1998); water level fluctuations with an amplitude of more than 6m; heavy floods (1968/69, 1991/92, 2002/03) and droughts (1973, 1989-1991, 1998-2002); low (1974, 1975, 1996, 1997 and almost totally absent during $2000-2002)$ and high $(1970,1987$, 1990, 1994, 1998) biomass of Peridinium; in winter of
2003 Peridinium reappeared after 4 years of absence; decline of zooplankton biomass during 1969-1993 and increase afterwards; low $(1983,1992)$ and high (1970, 1979, 1999) epilimnetic temperature. Hydrological, chemical and biological seasonal fluctuations are typical to subtropical climate conditions of the Kinneret region: high levels in winter and low in summer months (Figs 1 and 2) with the exception of high inventories of hypolimnetic dissolved phosphorus, ammonium, sulfdes and $\mathrm{CO}_{2}$ in summer - fall period. The lake ecosystem represented a high level of stability and did not deviate from resilient fluctuations (Gophen 2000). Long term record of hydrological parameters indicates a high amplitude of changes (Fig. 3) and repeated seasonal pattern (Fig. 4). Monthly means were averaged as: lake volume $4117 \times 10^{6} \mathrm{~m}^{3}$, inflow discharges $62.6 \times 10^{6} \mathrm{~m}^{3} \mathrm{month}^{-1}$, and rainfall $70 \mathrm{~mm}$. Multiannual fluctuations of water level ranged between $-214.87-208.57 \mathrm{~m}$ b.s.1. Monthly value of residence time ranged between 0.8 -51.6 years.

The lake is heavily exploited for its fishing by $c a$ 200 licensed fishermen which remove commercially an average of $1832 \mathrm{t} \mathrm{y}^{-1}$ of fish $\left(108 \mathrm{~kg} \mathrm{ha}^{-1}\right)$ (Tab. 1). 

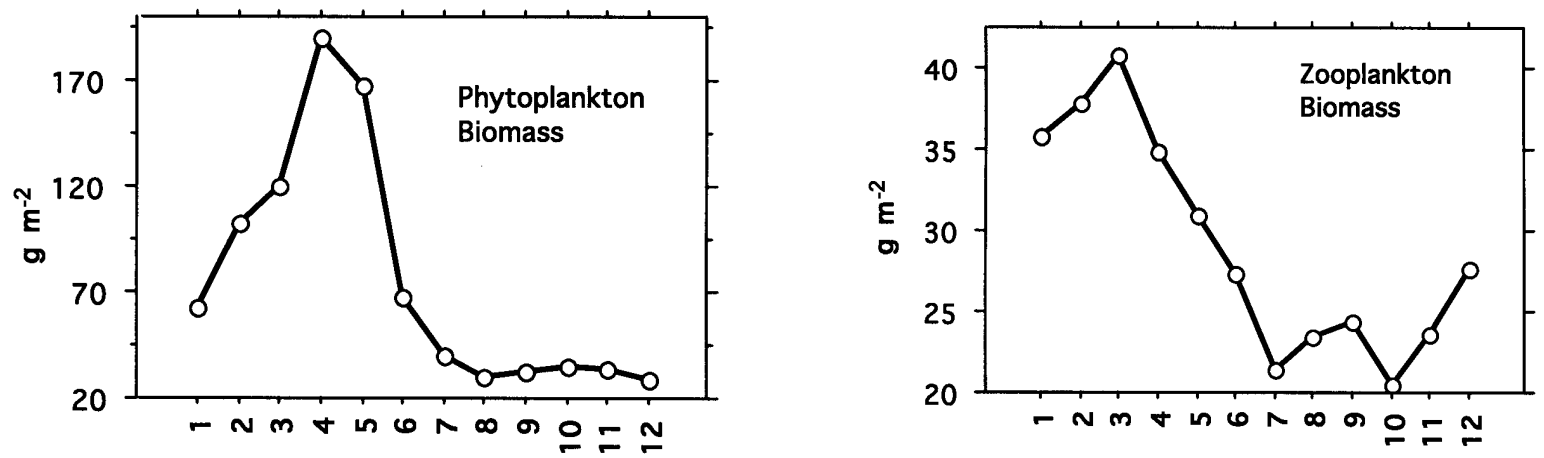

Fig. 1. Monthly means (1969 - 2001) of the biomass of total phytoplankton (left panel) and herbivorous zooplankton (right panel).
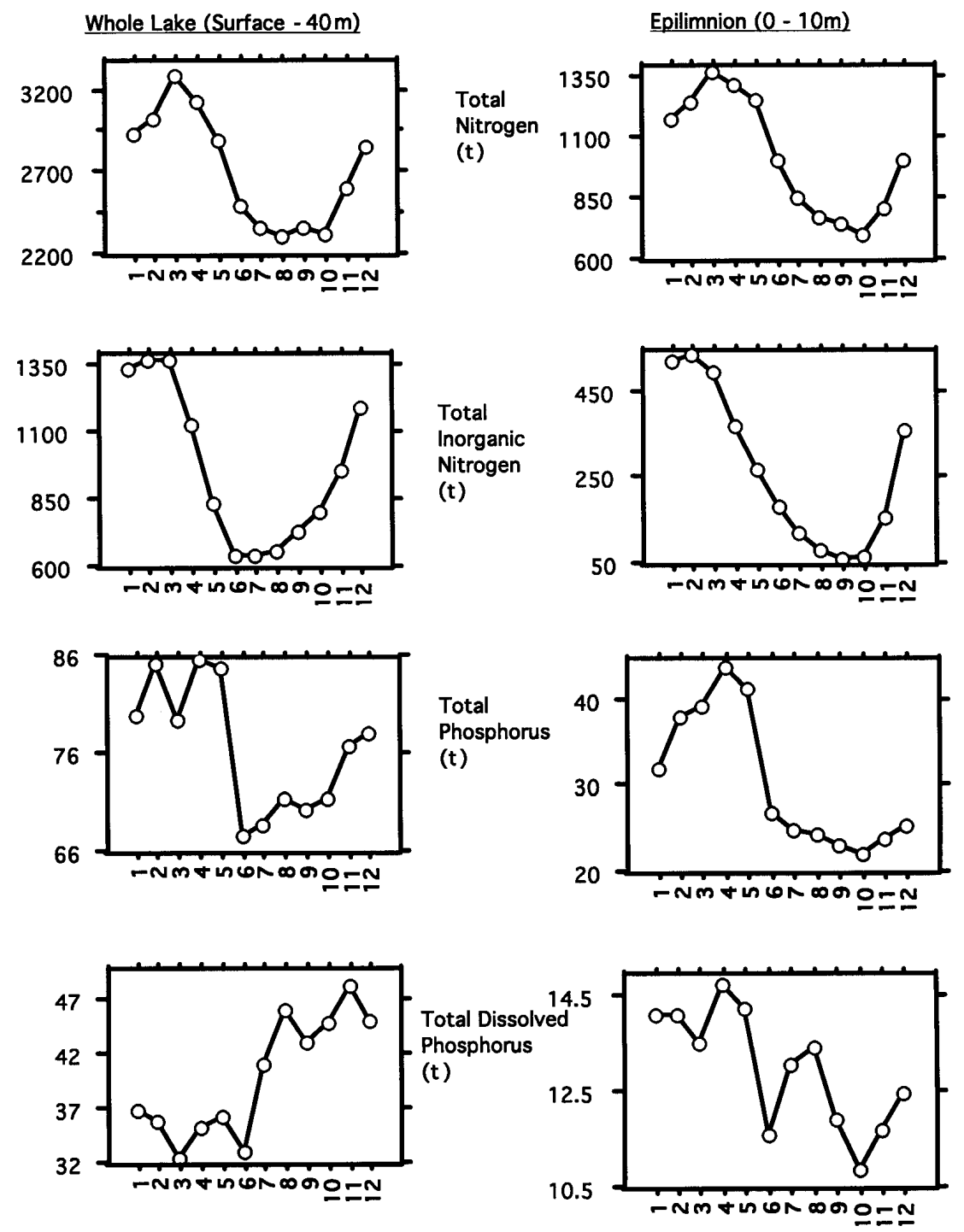

Fig. 2. Monthly means $(1969-2001)$ of the Kinneret nutrient inventories in the epilimnion and whole lake: total nitrogen, total inorganic nitrogen, total phosphorus, and total dissolved phosphorus. 


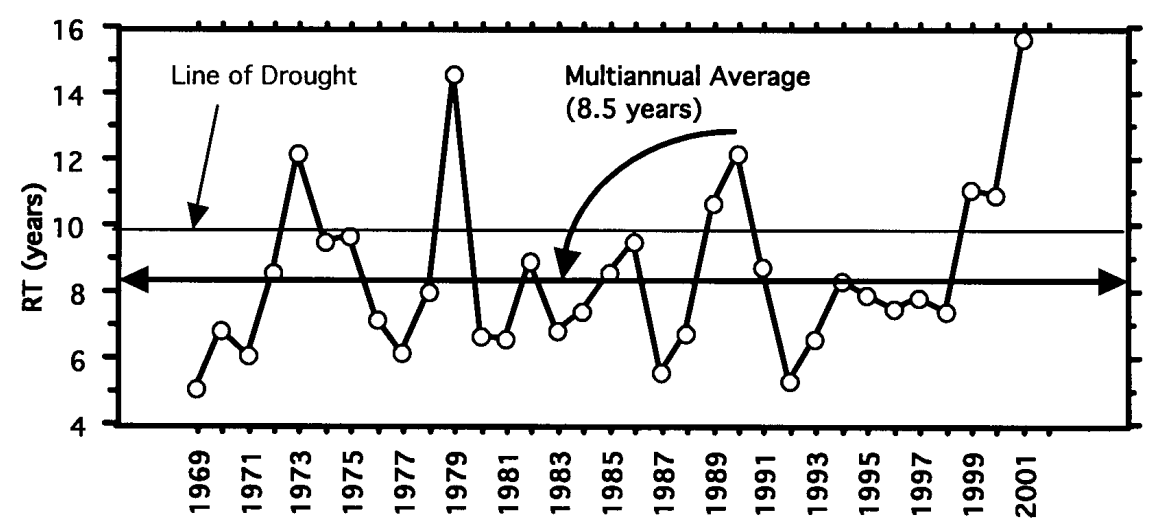

Fig. 3. Annual (1969 - 2001) averages of Residence Time values in Lake Kinneret. Drought and mean levels are indicated.
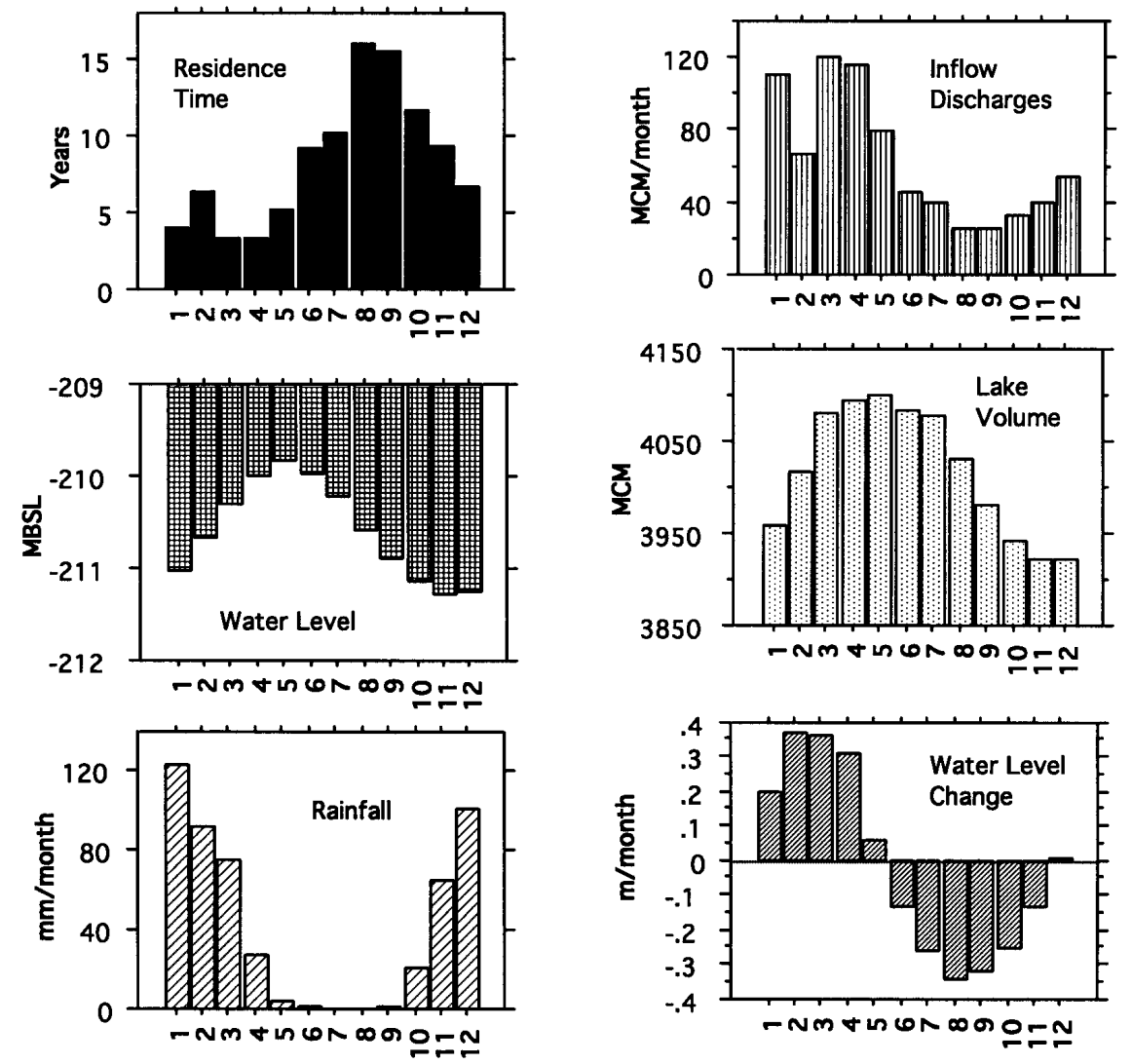

Fig. 4. Monthly $(1969-2001)$ means of Residence Time (in years), inflow discharges, $(\mathrm{mcm} / \mathrm{month}),\left(10^{6} \mathrm{~m}^{3}=\mathrm{MCM}\right)$, lake water level (m b.s.l. altitude), rainfall (Hula Valley) $(\mathrm{mm} / \mathrm{month})$, water level change (m/month). 
Tab. 1. Commercial fisheries in Lake Kinneret (averaged for 1988-1999) (SD): annual landings and market value.

\begin{tabular}{lccccc}
\hline \multirow{2}{*}{ Species } & \multicolumn{2}{c}{ Annual landing } & & \multicolumn{2}{c}{ Market value } \\
\cline { 2 - 3 } \cline { 5 - 6 } & $(\mathrm{t})$ & $(\%)$ & & $\left(\times 10^{3}\right.$ US \$) & $(\%)$ \\
\hline Sarotherodon galilaeus (Galilee St. Peter's Fish) & $377(110)$ & 21 & & 1750 & 48 \\
Oreochromis aureus (Jordan St. Peter's Fish) & $124(63)$ & 7 & & 345 & 9 \\
Tristramella spp. (Tritram's St. Peter's Fish) & $58(26)$ & 3 & & 87 & 2 \\
Mugil spp. (Gray Mullet) & $162(79)$ & 9 & & 825 & 23 \\
Barbus spp. (Barbel) & $39(23)$ & 2 & & 82 & 2 \\
Hypophthalmichthys molitrix (Silver Carp) & $64(50)$ & 3 & & 32 & 1 \\
Cyprinus carpio (Common carp) & $83(54)$ & 5 & & 242 & 7 \\
Acanthobrama spp. (Bleak) & $924(314)$ & 50 & & 277 & 8 \\
Total & $1832(362)$ & 100 & & 3640 & 100
\end{tabular}

The zooplanktivorous Lavnun (Bleak, Acanthobrama spp.) comprised $40-60 \%$ by weight of total catches and $>50 \%$ of the stock (Walline et al. 1993) (Tab. 2).Twenty-four fish species are known in Lake Kinneret, of which 19 are native and 5 exotic (BenTuvia 1978). Only eight species are commercially fished. The food web structure is dominated by planktivorous fishes. The dominant factor affecting annual catches is the yield of non-stocked fish, mostly Lavnun, and in turn, the annual yield of Lavnun is a function of fishing effort (Gophen et al. 1999a.).

Tab. 2. Lavnun fishery (commercial + subsidised) in Lake Kinneret during 1988-1998: total catches (T) of lavnun and \% of total fishery are presented (Sandovsky and Shapiro 1999).

\begin{tabular}{lcc}
\hline & \multicolumn{2}{c}{ Lavnun landings } \\
\cline { 2 - 3 } & $(\mathrm{t})$ & $(\%)$ \\
\hline 1988 & 882 & 65 \\
1989 & 1217 & 63 \\
1990 & 979 & 46 \\
1991 & 1025 & 46 \\
1992 & 1287 & 58 \\
1993 & 967 & 53 \\
1994 & 300 & 20 \\
1995 & 434 & 36 \\
1996 & 1155 & 63 \\
1997 & 626 & 42 \\
1998 & 1171 & 54 \\
1999 & 1048 & 49 \\
\hline
\end{tabular}

Fishing policy is aimed at both water quality protection and fish production. As a result of optimal reproduction condition during the winter of 1992 the lake was occupied by a dense population of sub-commercial size Lavnun resulted in elimination of commercial fishing. Consequently, zooplankton biomass and community grazing capacity were declined to the lowest level ever recorded (Fig. 6). A recommendation to subsidize removal of sub-commercial sized bleaks was implemented during 8 consecutive years (1995-2002) and about $4000 \mathrm{t}$ of small bodied Lavnun were removed ( $c a$ 400-500 $\mathrm{t} \mathrm{y}^{-1}$ ) and buried. Three years later, proportion of marketable sized ( $>13 \mathrm{~cm}$ TL) individuals in the population was enhanced and the commercial fishery of Lavnun was renewed (Tab. 2), after its dramatic decline during 1994-1995.

Three superimposed trophic cycles have been described in the Lake Kinneret ecosystem (Serruya et al. 1980): 1) the heavy bloom forming algae, Peridinium and its primary consumers-herbivorous planktivorous fish with Galilee St Peter's fish (Sarotherodon galilaeus) being the most efficient feeder among them; 2) nanoplanktonic algae (mainly chlorophytes, diatoms, and non- colonial cyanophytes), herbivorous zooplankters and zooplanktivorous fishes with Lavnun being the major zooplankton consumer; and 3) the microbial loopers including two major cycles: a) Peridinium (poorly utilized by zooplankton), detritus, associated bacteria and protozoa (Berman et al. 1995; Hadas and Berman 1998; Hadas et al. 1998), and their consumerzooplankton, and b) chemosynthetic sulfur bacteria and their zooplankton utilizers. Available food resources for zooplankton are primarily (top preference) nanophytoplankton with supplemental detritus, bacteria and protozoa (Zohary et al. 1994). The seasonal pattern of those trophic pathways are as follows: the Peridinium-fish channel is dominant during February-May; the nanophytoplankton-herbivorous zooplankton-zooplanktivory fish channel is dominant between June-November; The Peridinium mass degrading bacteria protozoa and detritus channel exist mostly during May-July and the chemosynthetic sulfur bacteria are common mostly during destratification period (October-January) (Hadas et al. 1998). Zooplankton predation is maintained also by adult cyclopoids: $70 \%$ of total ingested food of which $89 \%$ is Ceriodaphnia prey, $10 \%$ cannibalism and 1\% Bosmina (Gophen 1976; 1977; 1981; Serruya et al. 1980). Food sources preferences by zooplankton are given in table 8 (Gophen \& Azoulay 2002).

This paper is focused on analyzing trophic level control in Lake Kinneret ecosystem as an attempt to answer the following question: how nanophytoplankton and consequently water quality in Lake Kinneret is controlled? 

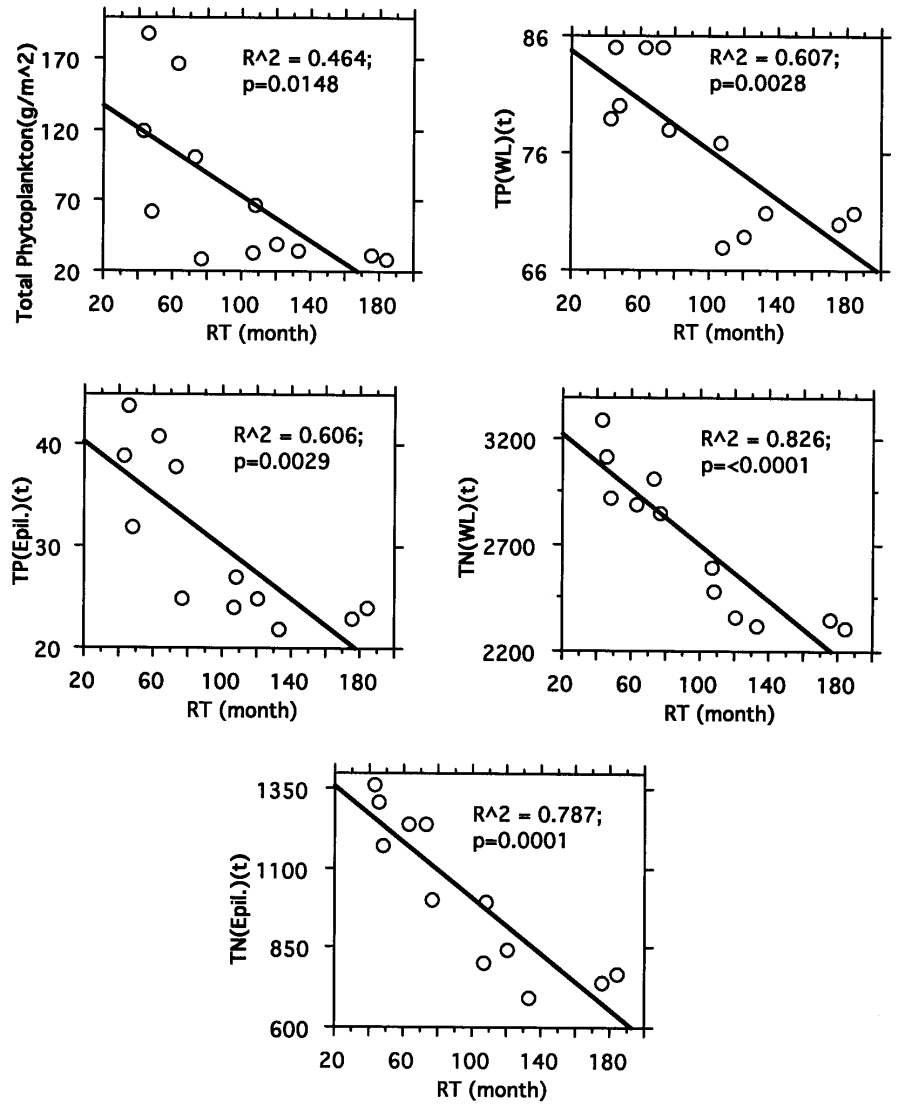

Fig. 5. Linear regressions between monthly means $(1969-2001)$ of total phytoplankton $\left(\mathrm{g} \mathrm{m}^{-2}\right)$, epilimnetic (Epil.) TP and TN loads (tons), whole lake (WL) TP and TN loads (tons), and Residence Time (in month) in Lake Kinneret during 1969-2001. Regression coefficients are given.

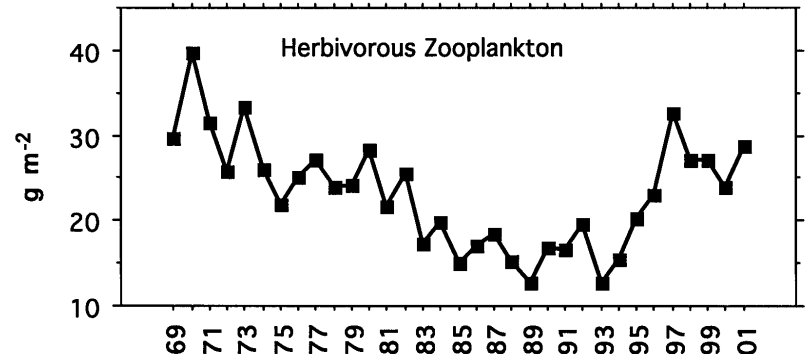

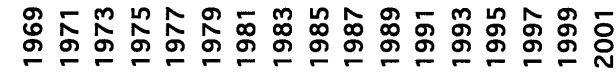

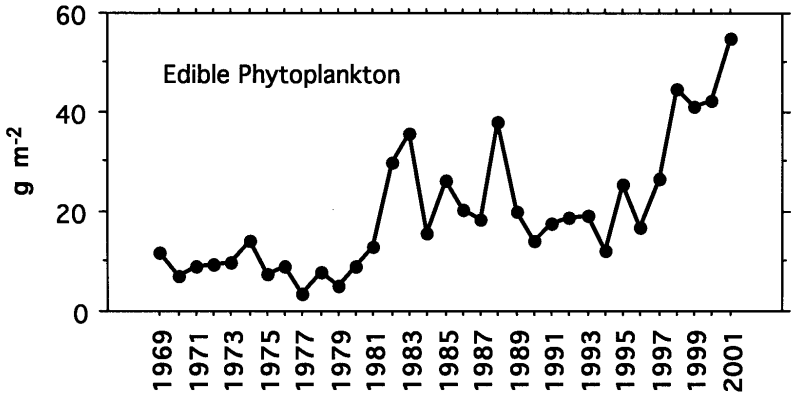

Fig. 6. Annual averages of herbivorous zooplankton (upper panel) and edible phytoplankton (Chlorophyte and Diatoms) (lower panel) biomass in Lake Kinneret during 1969-2001. Phytoplankton data source is Lake Kinneret Data Base, U. Pollingher and T. Zohary. 
Pressured by fish-zooplanktivory through zooplankton to nanophytoplankton biomass (top-down) or by nutrient availability through algal biomass with consequent enhancement of zooplankton biomass, and what is the impact of Residence Time.

\section{METHODS}

Sampling and analysis of zooplankton, phytoplankton, chlorophyll, primary production, total phosphorus (TP), total dissolved phosphorus (Ptd), particulate organic $\mathrm{N}$ (PON), dissolved organic $\mathrm{N}(\mathrm{DON})$, ammonia, nitrate, and nitrite i.e. total inorganic N (TIN), particulate P (part. P), were carried out routinely (1969 2001), and methods are given in previous reports and Gophen et al. (1999b). Data of phytoplankton (U. Pollingher and T. Zohary), zooplankton (M. Gophen), primary production (PP), chlorophyll, Secchi depth (Y.Z. Yacobi and T. Berman), and nutrients (A. Nishri) were taken from The Lake Kinneret DataBase (M. Schlichter manager). Carbon content values and coefficients are given in Serruya et al. (1980), Gophen (1976a, b, 1978, 1981) and Gophen \& Azoulay (2002).

\subsection{Statistical analysis}

ANOVA test (5\% significance level) was used to test the periodical and RT effects on monthly averages (1969 - 2001) of plankton biomass and metabolic activities distribution, and distribution of nutrient inventories. For periodical effect the years were grouped in 3 classes: 1: 1969-1982; 2: 1983-1992; 3: 1993-2001; and for RT effect monthly (1969 - 2001) RT values (years) were grouped in 5 classes: $1:>10.0 ; 2: 7.3-9.9 ; 3: 5.4$ $7.2 ; 4: 3.5-5.3 ; 5<3.4$.

\section{RESULTS}

\subsection{Carbon Flow Channels}

The carbon flow pathways within the food web was documented by Serruya et al. (1980), Walline et al. (1993), Gophen (1981), and Gophen \& Azoulay (2002). The food web carbon stock compartments were recalculated and averaged for the period of 1969-2001.

Plankton. Herbivorous zooplankton - $1.0 \mathrm{~g} \mathrm{C} \mathrm{m}^{-2}$; secondary production- $5.0 \mathrm{~g} \mathrm{C} \mathrm{m}^{-2} \mathrm{month}^{-1}$; herbivorous zooplankton respiration $-9.3 \mathrm{~g} \mathrm{C} \mathrm{m}^{-2} \mathrm{month}^{-1}$; food requirement of herbivorous zooplankton - $74 \mathrm{~g} \mathrm{C} \mathrm{m}^{-2}$ month $^{-1}$; defecation rate of herbivorous zooplankton - 60 $\mathrm{g} \mathrm{C} \mathrm{m}^{-2} \mathrm{month}^{-1}$; primary production - $52 \mathrm{~g} \mathrm{C} \mathrm{m}^{-2}$ month $^{-1}$.

Microbial loop. Bacterial biomass - $7 \mathrm{~g} \mathrm{~m}^{-2}$; protozoa biomass - $4 \mathrm{~g} \mathrm{~m}^{-2}$; food requirement of protozoa $-7 \mathrm{~g}$ $\mathrm{m}^{-2}$ day $^{-1}$; bacterial food requirement $-8 \mathrm{~g} \mathrm{~m}^{-2}$ day $^{-1}$; daily $\mathrm{P} / \mathrm{B}$ ratio of bacteria -0.58 (i.e. production of $4.1 \mathrm{~g}$ $\mathrm{m}^{-2}$ day $^{-1}$ ); daily $\mathrm{P} / \mathrm{B}$ ratio of protozoa - 0.82 (i.e. production of $3.3 \mathrm{~g} \mathrm{~m}^{-2} \mathrm{day}^{-1}$ ) (Walline et al. 1993).

Zooplankton data indicates $20 \%$ assimilation and $80 \%$ excretion (recycled) of ingested food by herbivo- rous organisms. On the other hand the production of bacteria and protozoa is $50 \%$ and $47 \%$ of food consumption respectively. Consequently, recycled nutrients by herbivorous zooplankters are higher than those of microbial loopers and organic matter decomposition by those organisms is high and their role as supplemental food resources for zooplankton is therefore significant (Serruya et al. 1980; Gophen 1981; Walline et al. 1993; Zohary et al. 1994).

The mean biomass of micro-zooplankton grazers (copepod nauplii and small rotifers) is $1.5 \mathrm{~g} \mathrm{~m}^{-2}$ and macro-grazers (copepodite stages, cladocerans and rotifers) mean biomass is $25.9 \mathrm{~g} \mathrm{~m}^{-2}$ (i.e. $95 \%$ of total grazing capacity as based on standing stock biomass). Experimental results indicated $5.6 \mathrm{mg} \mathrm{C} \mathrm{m}^{-2} \mathrm{month}^{-1}$ food consumption by micrograzers and $68.4 \mathrm{mg} \mathrm{C} \mathrm{m}^{-2}$ month $^{-1}$ by macrograzers for the whole lake. Consequently micrograzing capacity is $c a 8 \%$ of macrograzing.

Zooplankton predation is maintained mostly by fish (Gophen \& Landau 1977) and also by adult cyclopoids (Gophen 1976a, 1978, 1981; Serruya et al. 1980): 70\% of total ingested food of which $89 \%$ is Ceriodaphnia prey, 10\% cannibalism and 1\% Bosmina (Gophen 1976, 1977; Serruya et al. 1980). Food source preferences by herbivorous zooplankton indicates highest preference for algal matter and supplemental resources of microbial matter (Tab. 7 from Gophen \& Azoulay 2002). Food source for Lavnun in Lake Kinneret is mostly zooplankton (Gophen \& Landau 1977; Gophen \& Threlkeld 1986; Azoulay \& Gophen 1992 a, b; Gophen \& Scharf 1981).

The difference between food requirements and food availability for herbivore zooplankters was positive (26 $\mathrm{g} \mathrm{C} \mathrm{m}^{-2} \mathrm{month}^{-1}$ ) i.e. intensive grazing pressure during 1969-1982 and significantly declined to a negative value $\left(-5 \mathrm{~g} \mathrm{C} \mathrm{m}^{-2}\right.$ month $\left.^{-1}\right)$ i.e. low grazing pressure during 1983-1992. During 1994-2000 it was positive again but the change from period 2 to 3 was insignificant.

Nishri et al. (1998) documented zooplankton respiration being about $15-20 \%$ of photosynthetic DO production (PP) which is respective to total zooplankton production of $15 \%$ of PP presented here. Seasonal metabolic activity of zooplankton communities in Lake Kinneret indicated higher levels of respiration and grazing and decline of production in summer than in winter months. Nutrient excretion (recycling) as calculated from: Consumption $=$ Respiration + Production + Excretion, is higher in summer. The highest seasonal values of grazing, excretion, and respiration are due to May and June. Consequently, the lowest seasonal values of metabolic efficiencies $([\mathrm{R}+\mathrm{P} / \mathrm{C}]$ in $\%)$ occur in summer (at $24-28{ }^{\circ} \mathrm{C}$ ). The summer months is the season when algal response to zooplankton recycling is significant. That is because residence time is log as a result of low inflow discharges and high volume of the lake and therefore, external nutrient inputs are minimal and nutrient supply from zooplankton recycling is maximal 
(Serruya et al. 1980). Moreover, feeding rates (predation pressure) of Lavnun and predator cyclopoids on herbivorous zooplankton are maximal as well (Walline et al. 1993).

\subsection{Periodical effect}

Results of ANOVA test are given in table 3. Nitrogen decline from period 1 and onwards and insignificant change between period 2 and 3 is indicated; particulate $\mathrm{P}$ was increased in period 3; chlorophyll and PP were increased in period 3; phytoplankton was increased from 1969 to 1993 and the change after 1993 was insignificant; zooplankton declined from 1969 to 1993 and increased afterwards.

Tab. 3. Results of ANOVA test (StatView 1998) of period (1: 1969-1982; 2): 1983-1993; 3: 1994-2000) effect on the epilimnetic parameters of: nutrients $(\mathrm{t})(\mathrm{TN}, \mathrm{TIN}, \mathrm{PON}, \mathrm{DON}$, TP, Ptd, Part-P, DO), Chlorophyll $\left(\mathrm{mg} \mathrm{m}^{-2}\right)$, PP $\left(\mathrm{g} \mathrm{C} \mathrm{m}^{-2}\right.$ month $^{-1}$ ), chlorophytes and diatoms and total phytoplankton ( $\mathrm{g}$ $\mathrm{C} \mathrm{m}^{-2}$ ), copepods, cladocerans, rotifers, and total herbivorous zooplankton $\left(\mathrm{g} \mathrm{C} \mathrm{m}^{-2}\right)$, herbivorous zooplankton production, respiration, grazing, and defecation $\left(\mathrm{g} \mathrm{C} \mathrm{m}^{-2}\right.$ month $\left.^{-1}\right)$; changes from 1 to 2,1 to 3 and 2 to $3(\mathrm{D}=$ decrease, $\mathrm{I}=$ increase $)$ are indicated only when $p$ values were significant $(<0.05)$; NS $=$ not significant.

\begin{tabular}{lccc}
\hline Parameter & 1 to 2 & 1 to 3 & 2 to 3 \\
\hline TN & D & D & NS \\
TIN & I & NS & NS \\
PON & D & D & NS \\
DON & D & D & NS \\
TP & NS & NS & NS \\
Ptd & D & D & D \\
Part.-P & NS & I & I \\
DO & I & NS & D \\
Chlorophyll & NS & I & I \\
PP & NS & I & I \\
Edible algae & I & I & NS \\
Total phytoplankton & I & I & NS \\
Copepoda & D & D & NS \\
Cladocera & D & NS & I \\
Rotifera & NS & NS & I \\
Herbivorous zooplankton & D & NS & I \\
Total zooplankton & D & D & I \\
Herbivorous production & D & NS & I \\
Herbivorous respiration & D & NS & I \\
Herbivorous grazing & D & NS & I \\
Herbivorous defecation & D & NS & I \\
\hline
\end{tabular}

\subsection{Phosphorus effect}

Total phosphorus (TP) and particulate phosphorus (Part-P) simultaneously increased in the epilimnion and in the whole lake, when dissolved phosphorus (Ptd) declined. (Fig. 7). Soluble P fluxed into particles probably algal cells. The periodical analysis indicated enhancement of algal matter and Part.-P since early 1980's. Moreover, results in table 6 indicates increase of TP inventory in the lake when RT become shorter (higher inflow). It is therefore suggested that the impact of external inputs (higher inflow discharge with consequent shorter Residence Time) is more significant than internal source contributions of P. Internal TP fluxes, are due to geochemical processes and partly by Peridinium cysts $\mathrm{P}$ mediated) (Serruya et al. 1980). From early 1980's edible algae (chlorophytes and diatoms) were enhanced, Part.-P was increased, TP did not change and Ptd declined (Fig. 7; Tab. 3).

Tab. 4. Frequency distribution and ranges of Residence Time (RT) groups and seasonal occurrence in Lake Kinneret during 1969-2001.

\begin{tabular}{cccc}
\hline RT group & Existed during months Range (years) & Counts \\
\hline 1 & $5-12$ & $10.1-34.3$ & 112 \\
2 & $5-12$ & $7.4-10.0$ & 77 \\
3 & $1-12$ & $5.4-7.3$ & 82 \\
4 & $1-7$ & $3.6-5.3$ & 57 \\
5 & $1-5$ & $0.8-3.5$ & 65 \\
\hline
\end{tabular}

\subsection{Residence Time effect}

The hydrological parameters are seasonally (Fig. 4) and multiannually (1969 - 1970) (Fig. 3) fluctuated. Inflow discharges in relation to lake volume (RT) has probably dominant effect on nutrient inventories and consequently on algal production and water quality. Results in figure 4 indicates that in winter months high inflow discharges, when the lake volume is low, RT values are small (short) (groups 3-5). Results in tables 4, 5 and 6 and figures 1, 2, 4, and 5 indicates shorter RT in winter when water and nutrient inputs are maximal and the opposite in summer months when thermocline depths are shallower. Results in table 6 indicates increase of Peridinium, zooplankton, TP, TN, TIN, \% of Peridinium, herbivorous zooplankton biomass and epilimnetic DO when RT was shorter (groups 3-5). On the other hand cyanophytes biomass, $\%$ of nanoplankton, $\%$ of cyanophytes, and $\%$ of zooplankton predation relative to herbivory declined when RT was shorter. Figures 1, 2, and 5 indicates decline of nutrient loads and algal biomass when RT became longer. RT values did not indicate a clear multiannual (1969-2001) (Fig. 3) trend in spite of consistent lowering of WL from 1992 (lowest ever measured in summers of 2001 and 2002) and consequently lake volume (data is not shown here). Lowest water levels (WL) coincide with shortest RT and decline of epilimnetic nutrients. WL was low during droughts (Fig. 3) and high in years with heavy rainfall. Rainfall, inflow discharge and nutrient inputs in winter 2003 were exceptionally high ( $c a$ 50-60\% above multiannual means), and Peridinium reappeared in high biomass. Water level increased $4.64 \mathrm{~m}$ (from -214.42 to -209.78 ) within 136 days (9/12/02 - 29/4/03) and RT values were low. Because of the major effect of external inputs and to a lesser extend of the internal processes on nutrient loads in Lake Kinneret the recommended management, aimed at lake water quality protection, should be mostly directed towards nutrient removal in the drainage basin and/or loads reduction by pumping water for supply with no apprehensiveness of water quality deterioration by low WL. 

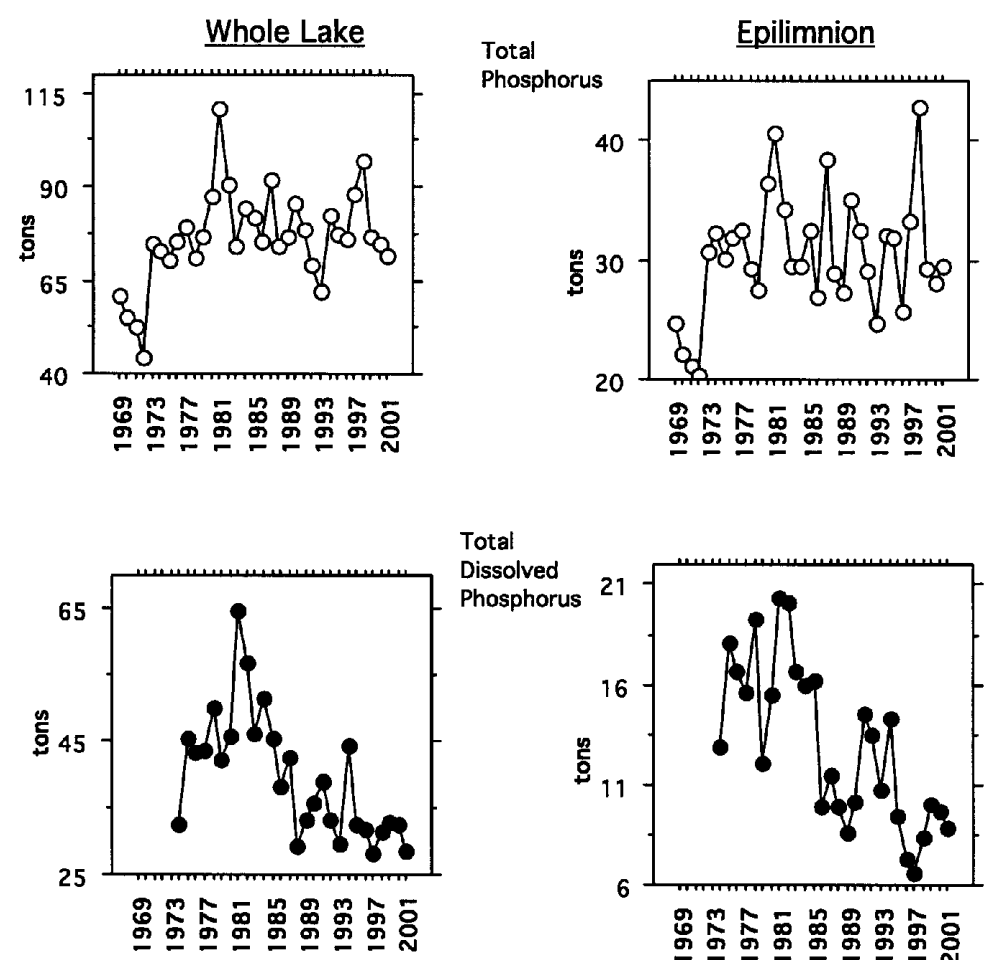

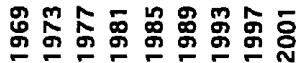
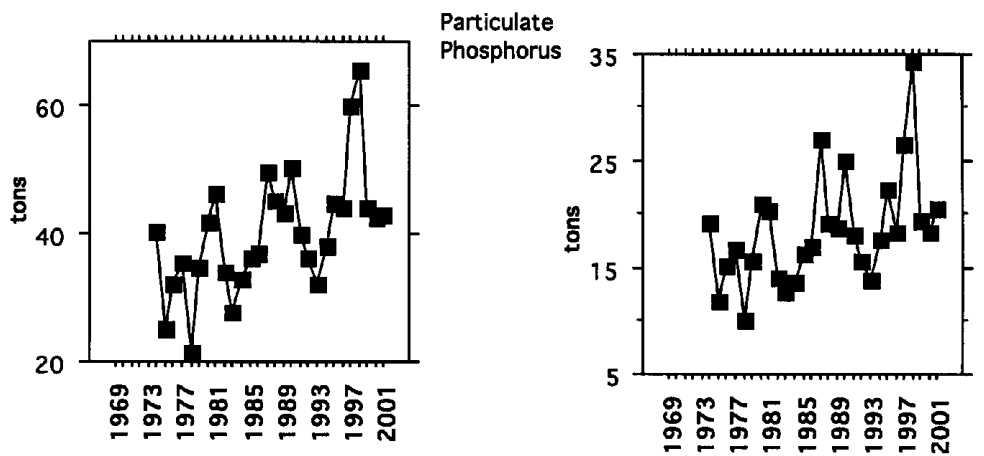

Fig. 7. Annual averages of Total P (TP), Total dissolved P (Ptd), Particulate P (Part.-P) in the epilimnion and whole Lake Kinneret during 1969-1999. Data source is Lake Kinneret Data Base, A. Nishri.

Tab. 5. Monthly Residence Time (in years) in Lake Kinneret during 1969 - 2000. Group sorting, counts, \% and the mean depth of the mid-thermocline for four 3-month periods (1: Jan.-Mar.; 2: Apr.-Jun.; 3: JulSep.; 4: Oct.-Dec.) are presented.

\begin{tabular}{|c|c|c|c|c|c|c|c|c|}
\hline \multirow[t]{2}{*}{ RT group } & \multicolumn{4}{|c|}{ Counts $(\%)$} & \multicolumn{4}{|c|}{ Mid-Thermoc. Mean depth } \\
\hline & 1 & 2 & 3 & 4 & 1 & 2 & 3 & 4 \\
\hline 1 & $2(2)$ & $9(10)$ & $64(69)$ & $24(26)$ & 36.2 & 15.9 & 18.7 & 21.4 \\
\hline 2 & $7(8)$ & $11(12)$ & $21(23)$ & $36(39)$ & 40.0 & 15.9 & 18.1 & 23.1 \\
\hline 3 & $25(27)$ & $21(23)$ & $6(6)$ & $26(28)$ & 39.3 & 18.6 & 17.1 & 26.4 \\
\hline 4 & $19(20)$ & $28(30)$ & $2(2)$ & $7(7)$ & 39.3 & 23.0 & 15.9 & 29.0 \\
\hline 5 & $40(43)$ & $24(25)$ & $0(0)$ & $0(0)$ & 39.7 & 33.6 & - & - \\
\hline
\end{tabular}


Tab. 6. Residence Time impact on limnological parameters in Lake Kinneret (1969-2002); ANOVA test of change $(>5 \%=$ not significant; $I=$ increase, $D=$ decrease $)$ between RT groups $(1-5)$ (see text): algae and zooplankton in $\mathrm{g} \mathrm{m}^{-2}$; nutrients in tons/epilimnion; Secchi depth; \% of algae from total phytoplankton; DO-mg $1^{-1}$; PP (primary production) and $\mathrm{SP}$ (secondary production) in $\mathrm{g} \mathrm{C} \mathrm{m}^{-2}$ month $^{-1}$.

\begin{tabular}{lcccccccccc}
\hline Parameter & 1 to 2 & 1 to 3 & 1 to 4 & 1 to 5 & 2 to 3 & 2 to 4 & 2 to 5 & 3 to 4 & 3 to 5 & 4 to 5 \\
\hline Diatoms & NS & NS & NS & NS & NS & NS & NS & NS & NS & NS \\
Chlorophyta & NS & NS & NS & NS & NS & NS & NS & NS & NS & NS \\
Cyanophyta & D & D & D & D & NS & NS & D & NS & NS & NS \\
Peridinium & NS & I & I & I & I & I & I & I & I & NS \\
Tot. Zoopl. & NS & I & I & I & I & I & I & NS & I & I \\
Tot. Phytopl. & NS & I & I & I & I & I & I & I & I & NS \\
TP-Epil. & NS & I & I & I & I & I & I & NS & I & I \\
TDP- Epil. & NS & NS & NS & I & NS & NS & I & NS & I & I \\
TN-Epil. & I & I & I & I & I & I & I & I & I & I \\
TIN-Epil. & I & I & I & I & I & I & I & I & I & I \\
\% Perid. & NS & I & I & I & I & I & I & I & I & NS \\
\% Nanopl. & NS & D & D & D & D & D & D & D & D & NS \\
\% Cyano. & NS & D & D & D & D & D & D & NS & NS & NS \\
Secchi & NS & NS & NS & NS & NS & NS & NS & NS & NS & NS \\
PP & D & NS & NS & NS & NS & I & I & I & I & NS \\
SP & NS & NS & NS & I & NS & NS & I & NS & I & I \\
Herb. Zoopl. & NS & I & I & I & I & I & I & NS & I & I \\
Zoopl. Graz. & NS & NS & NS & D & NS & NS & NS & NS & NS & D \\
DO- Epil. & NS & I & I & I & I & I & I & I & I & I \\
\%Pred. of Graz. Zoopl. & NS & NS & D & D & D & D & D & D & D & D \\
\hline
\end{tabular}

Tab. 7. Food preferences (biomass/C content) of zooplankton groups.

\begin{tabular}{lcccc}
\hline Food sources & \multicolumn{3}{c}{ Feeders } \\
\cline { 2 - 5 } & $\begin{array}{c}\text { Copepoda } \\
\text { (Herbivor.) }\end{array}$ & $\begin{array}{c}\text { Copepoda } \\
\text { (Predat.) }\end{array}$ & Cladocera & Rotifera \\
\hline Peridinium & 0 & 0 & 0 & 0.05 \\
Diatoms & 0 & 0 & 0.37 & 0 \\
Microcystis & 0.1 & 0 & 0.05 & 0.05 \\
Chlorophyta & 0.65 & 0.05 & 0.38 & 0.1 \\
Detritus & 0.25 & 0.1 & 0.2 & 0.75 \\
Cladocera & 0 & 0.65 & - & 0 \\
Rotifera & 0 & 0.05 & 0 & - \\
Copepoda (Herbivor.) & - & 0.1 & 0 & 0.05 \\
Copepoda (Predat.) & 0 & 0.05 & 0 & 0 \\
\hline
\end{tabular}

\section{DISCUSSION}

The Kinneret case analysis include phosphorus algal relations (bottom - up direction) and indirect effects of zooplankton predation by fish and consequent changes of grazing capacities (top-down direction). The nutrient effects on algal growth in Lake Kinneret was found to be effective (Berman et al. 1995; Pollingher et al. 1988) as well as fish predation on zooplankton communities (Gophen 1999a). P-limitation for algal production in Lake Kinneret was documented among others by Serruya et al. (1980), Pollingher et al. (1988), and Berman et al. (1995). The question to be answered is whether top-down or bottom-up is dominant and what is the effect of RT.

The biomass of herbivorous zooplankton declined since 1970-1993 and significant increase occurred later (Fig. 6). On the other hand, nanophytoplankton enhancement started in early 1980's (Fig. 6). During the 1970's when zooplankton grazing capacity was high - nanophytoplankton biomass was low (Fig. 6). Nanophytoplankton biomass was enhanced as a result of increasing levels of Part-P i.e. algal cells and their photosynthetic activity (PP) were accelerated. In spite of edible algal prosperity during the 1980 's, the biomass of herbivorous zooplankton declined until early 1990's with increasing values of cladoceran small/large ratios. It is suggested that those two parameters reflect an intensive predation pressure of fish on zooplankton. The increase of the ratio between small and large - bodied cladocerans was levelled off during the 1990's when Lavnun removal program was carried out (Fig. 8). Even if biomanipulation (Lavnun removal) did not reduce algal biomass stocks, the enhancement of zooplankton grazing (grazing rate of large cladocerans is higher than that of small bodied) probably suppressed PP contribution. Increase of large cladocerans relative to small (Fig. 4) and increase of grazer biomass were documented (Fig. 7) in late 1990's. The final result was a slight improvement of water quality by suppressing algal growth, 
expressed as levelling off the phytobiomass enhancement (NS change from period 2 to period 3) (Tab. 3). The efficiency of water quality improvement by Lavnun removal might be even higher if phosphorus inventory would be lower.
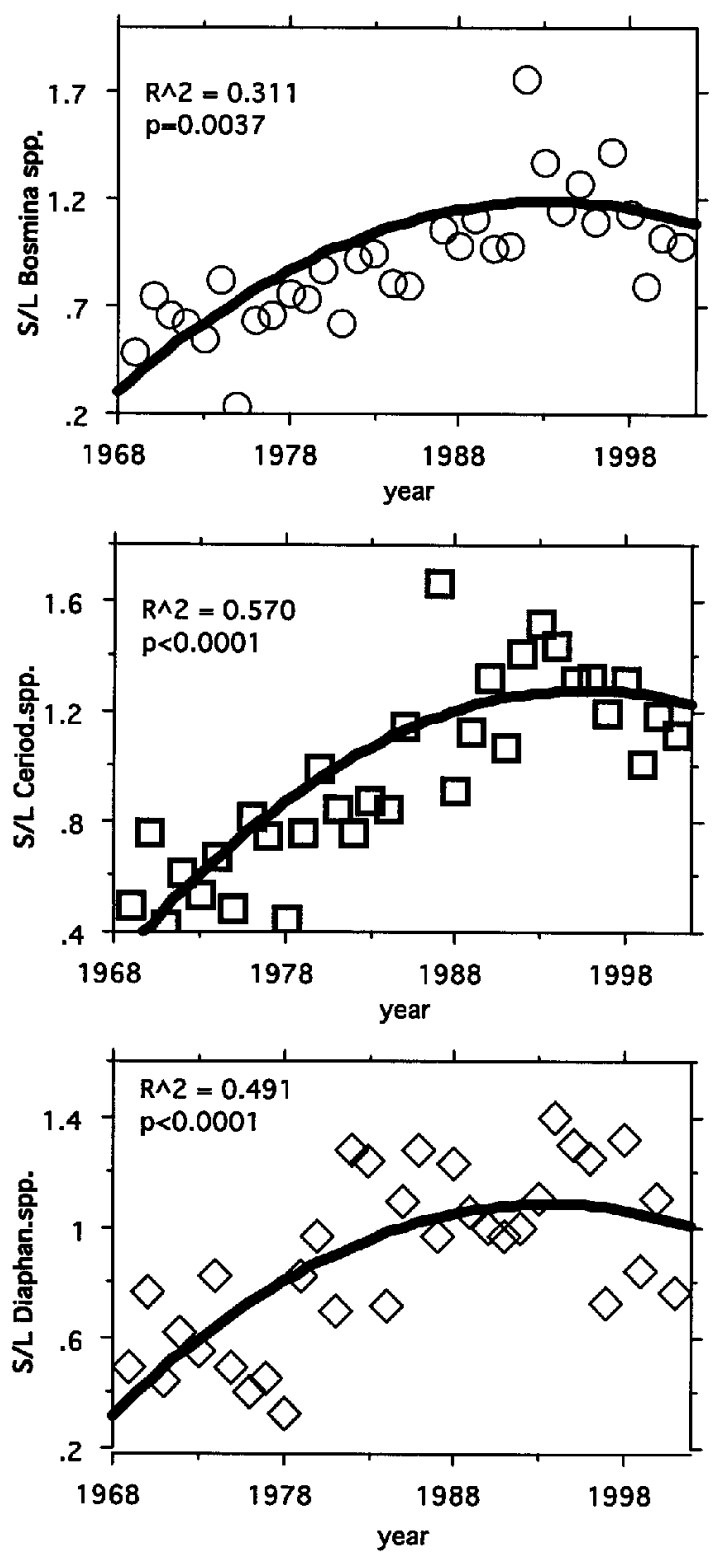

Fig. 8. Annual(1969 - 2001) averages of numerical density (No. $1^{-1}$ ) ratios between small (neonates 1-3) and large (neonates 3-5) cladocerans (Bosmina spp., Ceriodaphnia spp., and Diaphanosoma sp.) in Lake Kinneret during 1969-2001.

The period of 1998 - 2001 was a consequence of droughts (Fig. 3) with low discharges, decline of water level (and lake volume respectively) and consequently, high RT. Nutrient inputs were approximately $50 \%$ lower then the multiannual averages (data is not shown here) and lake inventories of $\mathrm{P}$ were declined. On the other hand, zooplankton biomass chlorophytes, diatoms and cyanophytes were enhanced. It is suggested that the zooplankton enhancement was initiated by reduction of fish predation pressure (Lavnun removal) and recycled $\mathrm{P}$ by zooplankters enhanced phytoplankton which partly improved zooplankton production later on as feed back effect.

The following sequence of long-term events can be outlined: Epilimnetic Part-P (mostly algal cells or their degrades) was enhanced from early 1980's and Ptd declined (from 1969 through 2001) mostly in summer months when $\mathrm{P}$ is limited as a result of uptake by algae which are P-limited and PP and chlorophyll increased during 1994-2001. As in oligotrophic systems (oceans, and lakes) throughout the year, in Lake Kinneret summer ecosystem nutrients (especially P) are limited (Serruya et al. 1980) and the epilimnion is functioned like a chemostat. Therefore enhanced Ptd algal uptake is significant when their biomass increase. This temporal effect might have also an impact on other months. Although recycled $\mathrm{P}$ might have a confound effect, the overall balance was Ptd decline. Independently, zooplankton grazing capacity was enhanced by Lavnun removal (1995-2003) and a slight algal suppression can be considered in the period of 1994-2001 (Tab. 3). Lake Kinneret is a mesotrophic lake with eutrophic level during the Peridinium bloom (February-June) and therefore Bendorf's hypothesis (2003) of phytoplankton biomass suppression resulted in from biomanipulation management is relevant. Lavnun removal was successfully operated by the fisheries authority, resulted in an increase of fish body size and partial renewal of commercial fishery. It make lowering of the cost of Lavnun removal (Gophen et al. 1999 a).

\section{CONCLUSIONS}

Biomanipulation (fishery) in Lake Kinneret included commercial removal of 950-1200 tons Lavnun per annum. On the other hand zooplankton enhancement increases levels of $\mathrm{P}$ recycling. Therefore it is required to reduce external $\mathrm{P}$ loading from the catchment together with the removal of about 1000 tons annually of Lavnun.

The major effect on nutrient loads in Lake Kinneret is due to inputs from the catchment and to a lesser extend to internal processes. Consequently, management implications aimed at lake water quality protection should be mostly directed towards nutrient removal in the drainage basin and lake loads reduction by pumping water for supply. When such a management is successfully implemented biomanipulation (Lavnun removal) might be efficient.

These two steps might reduce inventory of $\mathrm{P}$ in Lake Kinneret. If operations in the catchment will be efficient, $P$ stock can be reduced in the lake. If Lavnun removal will be sufficient, zooplankton enhancement might have positive impact on water quality by algal suppression. Zooplankton enhancement during 19942001 and not 10 years earlier is indicating two conclu- 
sions: 1) lake Kinneret is an ecosystem where biomanipulation can be successfully implemented; 2) zooplankton in Lake Kinneret is not food limited but topdown controlled by predators (predation limited).

\section{ACKNOWLEDGMENTS}

I am very grateful to colleagues and technicians in the Kinneret Limnological Laboratory for assistance and collaboration during unforgettable 34 years of Kinneret studies.

\section{REFERENCES}

Azoulay, B. \& M. Gophen. 1992a. Feeding Habits of Larval Mirograx terraesanctae (Steinitz 1952) in Lake Kinneret (Israel): I. Field Study. Hydrobiologia, 246: 243-249.

Azoulay, B. \& M. Gophen. 1992b. Feeding Habits of Larval Mirograx terraesanctae (Steinitz 1952) in Lake Kinneret (Israel): II. Experimental Study. Hydrobiologia, 246: 251258.

Benndorf, J., W. Boing, J. Koop, \& I. Neubauer. 2003. Top down control of phytoplankton: the role of time scale, lake depth and trophic state. Freshwater Biology: (in press).

Ben-Tuvia, A. 1978. Fishes. In: C. Serruya (Ed.), Lake Kinneret Monographiae Biologicae. Vol. 32. Junk Publishers, The Hague: 407-430.

Berman, T., L. Stone, Y.Z. Yacobi, B. Kaplan, M. Schlichter, A. Nishri \& U. Pollingher. 1995. Primary production and phytoplankton in Lake Kinneret: A long-term record (1972-1993). Limnol. Oceanogr., 40: 1054-1076.

Gophen, M. 1976a. Temperature Effect on Lifespan, Metabolism and Development time of Mesocyclops leuckarti (Claus). Oecologia (Berl), 25: 271-277.

Gophen, M. 1976b. Temperature dependence of food intake, ammonia excretion and respiration in Ceriodaphnia reticulata (Jurine) (Lake Kinneret, Israel). Freshwat. Biol., 6(6): 451-455.

Gophen, M. 1977. Food and feeding habits of Mesocyclops leuckarti (Claus) in Lake Kinneret (Israel). Freshwat. Biol., 7: 513-518.

Gophen, M. 1978. Zooplankton, In: C. Serruya (Ed.), Lake Kinneret Monographiae Biologicae. Vol.32. Junk publishers, The Hague: 297-311.

Gophen, M. 1981. Metabolic activity of herbivorous zooplankton in Lake Kinneret (Israel) during 1972-1977. J. Plankton Res., 3(1): 15-24.

Gophen, M. 2000. Lake Kinneret (Israel) ecosystem: longterm instability or resiliency? In: S. Belkin (Ed.), Envi- ronmental challenges. Water, air and soil pollution, Special Section. Kluwer Academic Publisher; 123(1-4): 323-335.

Gophen, M. \& R. Landau. 1977. Trophic interactions between zooplankton and sardine (Mirogrex terraesanctae) populations in Lake Kinneret, Israel. Oikos, 29(1): 166-174.

Gophen, M. \& A. Scharf. 1981. Food and feeding habits of Mirogrex fingerlings in Lake Kinneret (Israel). Hydrobiologia, 78(1): 3-9.

Gophen, M. \& S.T. Threlkeld. 1989. An experimental study of zooplankton consumption by the Lake Kinneret sardine. Arch. Hydrobiol., 115: 91-95.

Gophen, M., P. Walline, I. Ostrovsky, B. Azoulay \& J. Easton. 1999a. Water quality and fisheries management in Lake Kinneret, (Israel). In: J.G. Tundisi \& M. Straskaba (Eds), Theoretical reservoir ecology and its applications. International Institute of Ecology, Brazilian Academy.

Gophen, M., Val H. Smith, A. Nishri \& S.T. Threlkeld. 1999b. Nitrogen deficiency, phosphorus sufficiency, and the invasion of Lake Kinneret, Israel, by the $\mathrm{N}_{2}$-fixing cyanobacterium Aphanizomenon opvalisporum. Aquatic Sciences, 61: 1-14.

Gophen, M. \& B. Azoulay. 2002. The trophic status of zooplankton communities in Lake Kinneret (Israel). Verh. int. Ver. Limnol., 28: 836-839.

Hadas, O. \& T. Berman. 1998. Seasonal abundance and vertical distribution of Protozoa (flagellates, cilliates) and bacteria in Lake Kinneret, Israel. Aquatic Microbial Ecology, 14: 161-170.

Hadas, O., N.M. Rushansky, R. Pinkas \& T.E. Cappenberg. 1998. Grazing on autotrophic and heterotrophic picoplankton by ciliates isolated from Lake Kinneret (Israel). J. Plankton Res., 20: 1435-1448.

Nishri, A., T. Zohary, M. Gophen \& D. Wynne. 1998. Lake Kinneret dissolved oxygen regime reflects long term changes in ecosystem functioning. Biogeochemistry, 42: 253-283.

Pollingher, U., T. Berman, B. Kaplan, \& D. Scharf. 1988. Lake Kinneret phytoplankton: response to $\mathrm{N}$ and $\mathrm{P}$ enrichments in experiments and in nature. Hydrobiologia, 166: 65-75.

Sandovsky, Z. \& J Shapiro (Eds) 1999. The fisheries and aquaculture of Israel, in figures. The State of Israel, Minisrtry of Agriculture-Department of Fisheries: $54 \mathrm{pp}$.

Serruya, C., M. Gophen, \& U. Pollingher. 1980. Lake Kinneret: Carbon Flow Patterns and Ecosystem Management. Arch. Hydrobiol., 88(3): 265-302.

Walline, P., S. Pizanty, M. Gophen \& T. Berman. 1993. The Ecosystem of Lake Kinneret, Israel. ICES.C.M. 1990/L:39: 8 pp.

Zohary, T. J. Erez, M. Gophen, I. Berman-Frank \& M. Stiller. 1994. Seasonality of stable carbon isotopes within Lake Kinneret food web. Limnol. Oceanogr., 39: 1030-1043. 